\title{
Mapping the Global Effects of Heritage, Memory and Identity
}

\author{
JOHN GUNDERS
}

UNIVERSITY OF QUEENSLAND

Helmut K. Anheier and Yudhishthir R. Isar (eds), Heritage, Memory and Identity

Sage, London, 2011

ISBN 9780857023902

RRP AU $\$ 79.00(\mathrm{pb})$

Heritage, Memory and Identity is the fourth title in Sage's Cultures and Globalization series, after Conflicts and Tensions (2007), The Cultural Economy (2008) and Cultural Expression, Creativity and Innovation (2010), all edited by Anheier and Isar. A fifth volume, The New Metropolitan Age, is due for release in 2012, a prodigious effort in anyone's language. The series' stated purpose is to unravel the complex interactions between culture and globalisation that are too often hidden behind 'unsubstantiated generalizations' and 'unquestioned assumptions'. (1-2) Conventional understandings of this topic are often still connected to the role of the nation-state, a connection, the editors argue, which is no longer dominant, (2) and the series therefore seeks to explore the complex and reciprocal relationships between culture and globalisation through an inter- or cross-disciplinary perspective, focusing on the 
ways that they intertwine at transnational and global levels. The fundamental questions the series asks are whether globalisation has changed the way culture functions at a national level, whether the interaction of culture and globalisation has been influenced by increased transnational mobility and what influence they have on the dynamics of globalisation.

Issues of heritage, memory and identity have all been raised throughout the series (see, for instance, Rasoul Nejadmehr's account of exile, hybrid identity and cosmopolitanism in volume three, and Dacia Viejo Rose's typology of heritage destruction in volume one), ${ }^{1}$ but in the present title these themes are taken up centrally. The detailed introduction first places the three terms within current scholarship, providing both an essential literature review and a general overview of the topics and the ways they interrelate.

The editors note the different conceptions behind tangible and intangible heritage, and examine some of the unintended consequences of UNESCO's wellmeaning attempts to safeguard intangible cultural heritage, such as the inevitable archiving and petrification of cultural forms and their disarticulation from living traditions. They point out that the popularity in recent years of heritage preservation is tied to a nationalist agenda of identity creation, in which dominant 'national populations often impose their ideas of heritage on minority groups' (5) and while world heritage is described as part of the shared culture of humanity, it becomes the property of a national or sub-national group where it is used for 'territorial self-fashioning'. (3) Closely related to the growth of interest in cultural heritage is the prevalent notion of 'collective memory', a protean notion that is the hardest of the three terms to define. It is described as a selective memorialising of national history, that at its best can be a way of rehabilitating a traumatic past and at its worst can be a way of perpetuating those same resentments.

Together, cultural heritage and collective memory are closely linked to the notion of identity, a keyword of our time. The central task of the book is to examine the ways that heritage and memory are deployed to address the uncertainties about identity that often accompany the effects of globalisation. The editors see the three topics as a 'conceptual troika' that forms a composite discursive practice in which the nation builds itself a collective social memory, with all the inclusion and exclusion, domination and suppression, that this implies. 
The questions that the book sets out to ask, then, are how these issues of heritage, memory and identity operate as nation-building tools within the globalised context of international migration, hybrid identity, global tourism, and an international policy framework. Written specifically for this volume, each of the twenty-three essays that form the main part of the book tightly address the three themes. The bulk of the essays are organised into three sections: global approaches, regional realities, and fields and issues. The first section is deliberately global in focus and largely theoretical in scope, and contains nine essays ranging from James Wertsch and Doc Billingsley's discussion of the implicit narrative frameworks of collective memory and the active mediation of remembering, to Ien Ang's examination of the tension between the de- and re-territorialising of diaspora and the inherently territorialising concept of heritage. Also included are co-editor Isar's history of UNESCO's developing notion of heritage; Dacia Viejo-Rose on the war-time destruction and later reconstruction of cultural heritage; Tim Winter on the political economy of heritage; and Jean-Pierre Warnier on the fraught connection between the UN's 'Declaration on the Rights of Indigenous Peoples' and the often antagonistic agendas of indigenous people at a local or national level. The section concludes with three short chapters that consider the themes in relation to specific objects: Cristina Sánchez-Carretero and Carmen Ortiz on improvised public memorials; Liz Ševčenko on heritage and human rights; and Benjamin Morris on the connections between cultural heritage and the environment.

The second section, regional realities, narrows the focus to particular regions, exploring the way that the overarching themes discussed in the preceding section play out in terms of specific issues relating to different world regions. The seven essays in this section cover a wide range of global examples. Jagath Weerasinghe writes about living heritage and authenticity in Sri Lanka; Aurel Croissant and Paul W. Chambers discuss a territorial dispute between Cambodia and Thailand over an eleventh-century Hindu temple which has important-but different-nationalist meanings for both countries. There are two essays on the ways in which heritage tourism provides resources for, but also tensions within, the construction of a national identity: the first, by Susan Keitumetse, Laura McAtackney and Gobopaone Senata focuses on South Africa and the second, by Rosabelle Boswell, considers similar themes in relation to Mauritius, Zanzibar and 
Madagascar. There are also two essays on the tensions of remembering and national representation in post-communist societies: Dragan Klaic looks at the re-writing of Soviet-era cultural production within a neoliberal political economy, while Zala Volcic mobilises the theme of nostalgia to consider the way that commodification is used to create a new national identity building on memories of communist Yugoslavia. Finally, Lucina Jiménez López considers migratory flows, new technologies and cultural hybridity in relation to cultural heritage and memory in South America.

The final section, fields and issues, contains seven chapters that move back to the general issues surrounding the heritage/memory/identity problematic. Julie Thomas's analysis of two national museums of immigration (the Ellis Island Museum in New York and La Cité Nationale de l'Histoire de l'Immigration in Paris) looks at the interplay between diaspora and national heritage through the optic of the museum, while two chapters consider general principles against the fruitful example of Istanbul: Asu Aksoy and Kevin Robins explore the construction of heritage and identity via the example of policy-based gentrification of the district of Sulukule, a predominantly Roma (Gypsy) area, and Yael Navaro-Yashin analyses migrants' conceptual construction of the city, based of the materiality of its history. Two short chapters include Akiko Hashimoto's discussion of the often painful memory of World War II in the project of nation-building during a transitional period in Japanese history and Ananda Breed's exploration of theatre as a commemoration of the Rwandan genocide of 1994. Brian Schiff, Carolina Porto de Andrade and Mathilde Toulemonde discuss collective memory in terms of their research with Arab-Jewish mixed couples living in France and finally Esther ShalevGerz draws on three of her artistic projects to examine the role of memory in issues of place and identity.

The final two essays in the book, by anthropologist Henrietta L. Moore and geographer David Lowenthal, are invited commentaries on the relation of the heritage/memory/identity problematic to globalisation, and written in light of the contributions to the volume. Both writers considered the question in terms of the way that communication technologies have affected the relationship, and exacerbated the tensions between heritage and the multiple modernities discussed in the preceding essays: Moore in terms of the enthusiasm for Japanese culture in 
the west, and Lowenthal in his utopian call for globalisation to evoke a cosmopolitan heritage that eschews the inherent conflicts that typify so much heritage-based nation-building.

As is the case with the previous three volumes in the series, the final third of the book is given over to a set of 'indicator suites' of comparative cultural data relating to the three mobilising terms. As the section editor states: 'Their purpose is to offer an empirical portrait of key dimensions of the relationships between cultural change and globalization, while also presenting empirical evidence about the specific topic of the volume in question.' (287) Most of the data is presented graphically, usually in chart or graph form, but each suite includes a short commentary summarising the information and spelling out the major consequences. There are twenty suites included in this volume, divided among the three main themes, although the editor acknowledges that there is considerable overlap with some of the data. Under heritage, the suites are world heritage sites, legal and political frameworks, museums, intangible heritage, tourism, sustainability, and international organisations and heritage, and include such information as the numbers of heritage sites by global region, museum attendance, numbers of endangered languages, and indexes of life satisfaction, health and ecological behaviour. Under memory, the suites are memorialisation, contested memories, global collective memories, places, media, migration and diaspora, and education. This section presents data such as opinions about religion and belief systems, and historic world events, as well as the foreign-born population of major US cities, global levels of education and, perhaps most bizarrely, the eight most popular national destinations of Japanese honeymooners (Australia is sixth with 6 per cent). Under identity, the suites are geographical identities, internet identities, multiple citizenship, popular culture, identities in the economy, and religion. As an example, the popular culture suite includes listings of the top ten popular songs across fifteen countries by nationality of the artist and the most popular national and international TV series in Sweden, Germany, Austria, Slovakia, Turkey and India.

The book, perhaps inevitably, betrays a slight European and North American bias in terms of the location of its authors, and especially in relation to the data included in the indicator suites, but I suspect the editors have been as catholic as they can in the circumstances and have sourced essays from three academics from 
Botswana and three Australians, as well as content from Mexico, Serbia, South Africa, Sri Lanka, Thailand and Turkey. Not all contributors are academics: Esther Shalev-Gerz brings her experience as an artist to her essay on language, voice and memory, and other arts practitioners and curators have contributed to the seventeen text boxes throughout the book that provide background material or relevant case studies. The various chapters reveal a range of backgrounds and methodologies, with approaches from anthropology, sociology, cultural studies, cultural policy studies, economics and social psychology, and while many of the essays rely on ethnography, there are other forms of analysis at work as authors draw on archaeology, history, memory work and theatre studies, to name a few, to interrogate the defining themes. The book is as comprehensive as it can be given the scope of the topic, and while it cannot cover every aspect of heritage, memory and identity in every region, the selections are interesting and valuable. The volumes in the Cultures and Globalization series look set to become standard works in the field, and Heritage, Memory, and Identity is no exception: essential reading for anyone with an interest in the way these topics interact.

John Gunders is an honorary research consultant at the Centre for Critical and Cultural Studies, University of Queensland. His current research is in the area of heritage reconstruction and its relation to globalisation.

\footnotetext{
-NOTES

${ }^{1}$ Rasoul Nejadmehr, 'Exile, Culture and Identity' in Helmut K. Anheier and Yudhishthir R. Isar (eds), Cultural Expression, Creativity and Innovation, Sage, London, 2010, pp. 99-104; Dacia Viejo Rose, 'Conflict and the Deliberate Destruction of Cultural Heritage' in Helmut K. Anheier and Yudhishthir R. Isar (ed.), Conflicts and Tensions, pp. 102-16.
} 